\title{
PENGARUH KETERAMPILAN MANAJERIAL KEPALA SEKOLAH DAN PEMBERIAN REWARD TERHADAP KINERJA GURU: PERAN MOTIVASI GURU SEBAGAI VARIABEL MEDIASI
}

\author{
Josua Manik $^{1}$, Marlinda Siahaan ${ }^{2}$ \\ ${ }^{12}$ Universitas Advent Indonesia \\ Email: joshua.himes@gmail.com
}

\begin{abstract}
ABSTRAK
Penelitian ini bertujuan untuk mengetahui pengaruh keterampilan manajerial kepala sekolah dan pemberian reward terhadap kinerja guru melalui motivasi guru. Penelitian ini menggunakan pendekatan kuantitatif. Data pada penelitian ini diolah menggunakan analisis jalur dengan menggunakan program Smart PLS. Hasil penelitian menunjukkan bahwa secara parsial keterampilan manajerial berpengaruh terhadap kinerja guru sekaligus motivasi kerja. Secara parsial pemberian reward juga berpengaruh terhadap kinerja guru dan motivasi kerja. Hasil lain dari uji path analysis menemukan bahwa secara tidak langsung motivasi dapat mempengaruhi hubungan antara keterampilan manajerial terhadap kinerja guru juga pemberian reward terhadap kinerja guru. hasil ini menggambarkan bahwa dengan adanya keterampilan manajerial kepala sekolah yang baik dan pemberian reward yang sesuai dapat meningkatkan motivasi guru sehingga berdampak pula pada hasil kerja yang maksimal.
\end{abstract}

Kata kunci: keterampilan manajerial kepala sekolah, pemberian reward, kinerja guru, motivasi guru

\begin{abstract}
This study aims to determine the effect of the principal's managerial skills and the provision of rewards on teacher performance through teacher motivation. This study uses a quantitative approach. The population in this study was 100 with a total sampling technique of sampling. The data in this study were processed using path analysis or path analysis assisted by the Smart PLS program. The results showed that partially managerial skills affect teacher performance as well as work motivation. Partially giving rewards also affect teacher performance and work motivation. Another result of the path analysis test found that indirectly motivation can affect the relationship between managerial skills on teacher performance as well as giving rewards to teacher performance. These results illustrate that the presence of good principal managerial skills and the provision of appropriate rewards can increase teacher motivation so that it also has an impact on maximum work results.
\end{abstract}

Keywords: principal managerial skills, giving rewards, teacher performance, teacher motivation 


\section{PENDAHULUAN}

Tiba pada era digital menghadapkan bangsa pada beragam tantangan. Salah satunya dalam hal Pendidikan. Di zaman yang telah berkembang ini, kualitas pendidikan menjadi hal yang wajib menjadi pembicaraan inti karena kualitas pendidikan sangat menentukan gerak laju pembangunan sebuah negara, sehingga, kualitas pendidikan dianggap sangat penting ${ }^{1}$. Oleh sebab itu, semua elemen masyarakat negara di dunia berlomba-lomba untuk meningkatkan kualitas pendidikannya sebagai upaya peningkatan kualitas hidup mereka. Selain tu, kualitas pendidikan tidak bisa dilepaskan dari peran guru yang terlibat dalam meningkatkan kualitas pendidikan itu sendiri. Sehingga, guru memiliki posisi dan peranan penting dalam strategi peningkatan kualitas pendidikan dan seluruh upaya peningkatan mutu pendidikan ${ }^{2}$. Dalam penelitian lain, ${ }^{3}$ menyatakan bahwa guru merupakan ujung tombak penentu dalam sistem pendidikan yang harus mendapatkan perhatian penting dan utama.

Salah satu yang menjadi permasalahan dunia pendidikan adalah kurangnya daya serap peserta didik, serta rendahnya mutu pendidikan diindonesia dikarenakan kualitas pengajar yang masih belum menguasai teknologi. Tidak hanya itu rendahnya mutu dan relevansi pendiidkan diiindonesia juga disebabkan oleh rendahnya kualitas tenaga pendidik. Salah satu factornya adalah pendidik tidak menggali potensi diri siswa dan mengembangkan potensi siswa ${ }^{4}$. Tetapi pendidik memaksakan siswa dapat mengikuti pelaksanaan pembelajaran dan berharap semua yang diajarkan dapat dipahami oleh siswa. Guru merupakan kunci keberhasilan pendidikan karena inti dari pendidikan adalah belajar dan mengajar. Factor yang juga menjadi penyebab rendahnya mutu pendidikan adalah kepuasan kerja guru, dimana akan timbul gejala seperti kemangkiran, malas bekerja, banyak keluhan guru, rendhnya prestasi kerja, serta rendahnya kualitas pengajaran, serta gejala negative lainnya. Oleh karena itu, tanpa didukung oleh guru yang professional dan berkualitas, upaya perbaikan apapun tidak akan memberikan perubahan yang signifikan dalam meningkatkan kualitas pendidikan. Dengan kata lain, peningkatan kualitas

\footnotetext{
${ }^{1}$ Dini Palupi Putri, "Pendidikan Karakter Pada Anak Sekolah Dasar Di Era Digital," ARRIAYAH : Jurnal Pendidikan Dasar (2018).

2 Kerry Elliott, "Teacher Performance Appraisal: More about Performance or Development?," Australian Journal of Teacher Education (2015).

${ }^{3}$ Septi Andriani, Nila Kesumawati, and Muhammad Kristiawan, "The Influence of the Transformational Leadership and Work Motivation on Teachers Performance," International Journal of Scientific and Technology Research (2018).

4 Yudie Irawan, Nanik Susanti, and Wiwit Agus Triyanto, "ANALISA DAN PERANCANGAN SISTEM PEMBELAJARAN ONLINE (E-LEARNING) PADA SMK MAMBAUL FALAH KUDUS," Simetris: Jurnal Teknik Mesin, Elektro dan Ilmu Komputer (2015).
} 
pendidikan harus dimulai dari peningkatan kinerja yang dilakukan guru ${ }^{5}$.

Dalam hal peningkatan kinerja guru maka di dalam prosesnya juga melibatkan keterampilan manajerial kepala sekolah. Ketera mpilan ini menjadi hal yang wajib dikuasai oleh seorang kepala sekolah ${ }^{6}$. Kegiatan dalam keterampilan ini secara umum berupa perencanaan, pengorganisasian, kepememimpinan, pemonitoran yang termasuk ke dalam tiga kategori penting terutama jika kepala sekolah akan menunjukkan fungsinya pada aturan yang memadai seperti (1) kemampuan konseptual, (2) hubungan manusia, dan (3) kemampuan teknis. Dengan kemampuan manajerial yang baik, kepala sekolahapkan mampu menjadi pendorong dan penggerak disiplin bagi guru agar mereka mampu meningkatatkan produktivitas kinerjanya dengan baik ${ }^{7}$.

Hal tersebut sesuai dengan penelitian Heather K.Spence Laschinger et al ${ }^{8}$ menemukan hahwa kepuasan kerja berpengaruh signifikan positif terhadap kinerja pegawai. Menurut ${ }^{9}$ menyatakan bahwa "Kinerja adalah sebagai suatu fungsi dan interaksi antara kemampuan dan inovasi". Peningkatan kinerja dapat didorong melalui pemberian penguatan dimana, menurut teori belajar behavioristik, pemberian reward dan punishment dapat memperkuat dan melemahkan respon positif ataupun negatif ${ }^{10}$. Menurut ${ }^{11}$, pemberian reward dan punishment tidak hanya terbukti efektif dalam praktek pendidikan/pembelajaran, tetapi juga pada dunia kerja. Pemberian punhisment melemahkan perilaku negatif sedangkan pemberian reward akan memperkuat perilaku positif. Selain itu, Pemberian reward diharapkan mampu mendorong semangat kerja para guru melalui peningkatan sejumlah parameter kinerja yang ditetapkan, sehingga bisa memahami kekurangan dan kelebihannya masing-masing dalam melaksanakan proses pembelajaran.

Peningkatan kerja guru dapat dilakukan melalui motivasi. Guru yang termotivasi akan proaktif dalam pekerjaannya sehingga akan menimbulkan kepuasan kerja karena memenuhi kebutuhan guru akan membantunya

5 Siti Makhmudah, "Upaya Memperbaiki Kualitas Guru Dengan Memaksimalkan Terpenuhinya Kompetensi Kepribadian Dan Profesionalisme Guru," Jurnal Studi Islam (2016).

${ }^{6}$ Yulekhah Ariyanti, "Keterampilan Manajerial Kepala Sekolah Dalam Meningkatkan Kinerja Guru,” AKSES: Jurnal Ekonomi dan Bisnis (2020).

${ }^{7}$ Syukri, "Peranan Kepemimpinan Kepala Sekolah Dalam Meningkatkan Kinerja Guru Pada SMP Nurul Ihsan Kabupaten Tolitoli," Tesis, 2012.

${ }^{8}$ Heather K.Spence Laschinger et al., "A Longitudinal Analysis of the Impact of Workplace Empowerment on Work Satisfaction," Journal of Organizational Behavior (2004).

${ }^{9}$ Yuan Li, Yongbin Zhao, and Yi Liu, "The Relationship between HRM, Technology Innovation and Performance in China," International Journal of Manpower (2006).

${ }^{10}$ Aissah Qomaria Azis and Suwatno Suwatno, "Pengaruh Gaya Kepemimpinan Kepala Sekolah Terhadap Kinerja Guru Di SMK Negeri 11 Bandung," Jurnal Pendidikan Manajemen Perkantoran (2019).

11 Zuhdiah Zuhdiah, "MENINGKATKAN MOTIVASI KERJA GURU MELALUI PEMBERIAN REWARD DAN PUNISHMENT,” Vidya Karya (2019). 
meningkatkan kinerjanya ${ }^{12}$. Motivasi perlu dipelihara dan dibina agar dapat mencapai tujuan organisasi yang diharapkan. Harapanya adalah melalui inspirasi para guru, guru akan terus tumbuh, berkembang dan bekerja keras untuk mencapai hasil yang maksimal. Begitu pula dengan motivasi kerja akan menambah warna kinerja seorang guru. Motivasi kerja merupakan pencerminan dari keinginan, harapan, dan cita-cita untuk mencapai hasil yang berhubungan dengan pekerjaan melalui sarana untuk mencapai hasil yang terbaik. Berdasarkan alasan yang diidentifikasi, penelitian ini dilakukan di sini untuk mengetahui pengaruh penghargaan terhadap kinerja guru, dimediasi oleh keterampilan manajerial kepala sekolah dan motivasi guru.

\section{KAJIAN TEORI Kinerja Guru}

Kinerja guru dapat dipantau dan diukur berdasarkan spesifikasi teknis atau kriteria keterampilan yang harus dimiliki setiap guru. Perilaku yang dipertimbangkan dalam kaitannya dengan aktivitas guru adalah aktivitas guru dalam proses pembelajaran. Kinerja guru dapat dilihat di dalam kelas, dalam interaksi pembelajaran, antara lain dalam bentuk kurikulum semester dan persiapan mengajar. Tentang pentingnya mengevaluasi pekerjaan guru ${ }^{13}$. Departemen Pendidikan Georgia mengembangkan alat penilaian kinerja guru, yang kemudian dikembangkan oleh Departemen Pendidikan Nasional sebagai alat penilaian kompetensi guru (APKG) ${ }^{14}$. Alat penilaian kompetensi guru meliputi: (1) rencana pembelajaran (teaching plans and materials) atau biasa disebut RPP (Rencana Pelaksanaan Pembelajaran); (2) prosedur pelatihan (classroom procedure); (3) komunikasi antarpribadi (interpersonal skill). Peraturan Menteri Pendidikan Nasional (Permendiknas) No. 41 Tahun 2007 memuat ukuran dan indikator untuk mengukur kinerja guru ${ }^{15}$, seperti terlihat pada tabel di bawah ini.

${ }^{12}$ Ani Suhartatik and P.Julius F Nagel, "Pengaruh Faktor Motivasi Terhadap Kepuasan Kerja Dan Kinerja Pada Guru Sekolah Menegah Atas (SMA) Di Surabaya," Prosiding Seminar Nasional Multi Disiplin Ilmu \& Call For Pappers UNISBANK (SENDI_U) (2016).

13 Özcan Özyurt et al., "Evaluation of an Adaptive and Intelligent Educational Hypermedia for Enhanced Individual Learning of Mathematics: A Qualitative Study," Expert Systems with Applications (2012).

14 Jamalullail Abdul Wahab et al., "Headmasters' Instructional Leadership and Its Relationship with Teachers Performance," Universal Journal of Educational Research (2020).

${ }_{15}$ Andhika Imam Kartomo and Slameto Slameto, "EVALUASI KINERJA GURU BERSERTIFIKASI,” Kelola: Jurnal Manajemen Pendidikan (2016). 


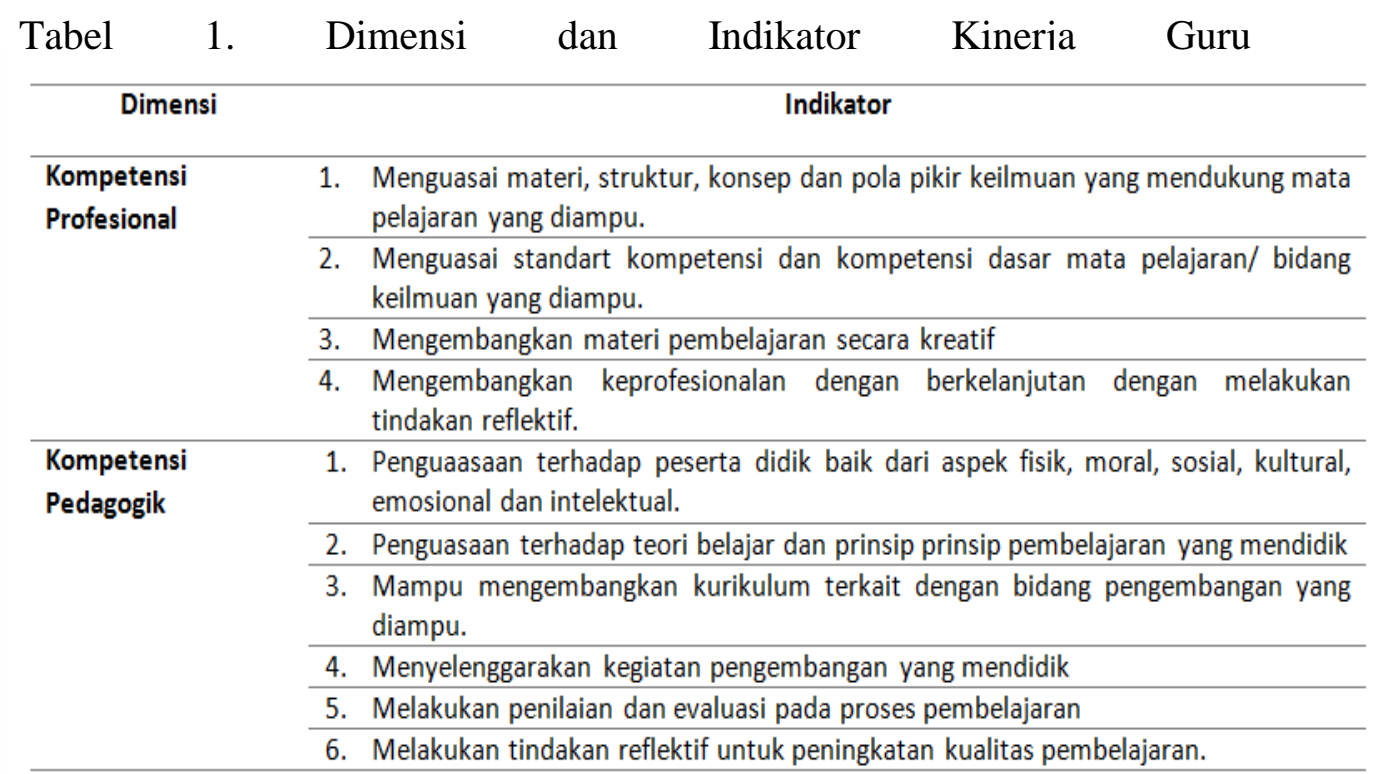

\section{Keterampilan Manajerial Kepala Sekolah}

Istilah "keterampilan" mengacu pada kemampuan seseorang untuk melakukan berbagai macam kognitif atau tindakan yang diperlukan secara efektif. Keterampilan manajerial kepala sekolah mengacu pada kumpulan kemampuan yang diperoleh kepala sekolah untuk mengelola sekolah dengan mengarahkan beragam sumber daya yang tersedia untuk mencapai tujuan sekolah yang telah ditentukan. Dalam pendidikan formal, kepala sekolah sebagai manajer berkewajiban untuk menunjukkan bakat manajerial dalam melaksanakan tugas dan tanggung jawabnya untuk mencapai tujuan proses belajar mengajar secara keseluruhan ${ }^{16}$. Sebagai manajer, kepala sekolah bertanggung jawab untuk memaksimalkan penggunaan semua sumber daya sekolah, termasuk manusia dan sumber daya lainnya, untuk mencapai standar pendidikan yang tinggi. Cara berpikir suatu lembaga akan sangat berpengaruh, jika tidak menentukan, terhadap keberhasilannya ${ }^{17}$. Dengan demikian, harus mampu mempengaruhi, mendorong, membimbing, mengarahkan, dan menggerakkan pengajar, staf, siswa, orang tua, dan pemangku kepentingan lainnya untuk berpartisipasi dalam mencapai tujuan lembaga. Indikasi berikut digunakan untuk menilai kemampuan administratif kepala sekolah ${ }^{18}$ : (1) perencanaan (planning), (2) pengorganisasian (organizing), (3) pelaksanaan (actuating), dan (4) pengawasan (controlling).

${ }^{16}$ Bagus Saputra, "KETERAMPILAN MANAJERIAL KEPALA SEKOLAH PADA SEKOLAH UMUM BERCIRI KHAS ISLAM DI SEKOLAH DASAR ISLAM TERPADU (SDIT)," Jurnal Manajemen dan Supervisi Pendidikan (2018).

${ }^{17}$ Rasdi Ekosiswoyo, "Kepemimpinan Kepala Sekolah Yang Efektif Kunci Pencapaian Kualitas Pendidikan,” Jurnal Ilmu Pendidikan (2016).

${ }^{18}$ Muhamad Sholeh, "Keefektifan Peran Kepala Sekolah Dalam Meningkatkan Kinerja Guru,” Jurnal Dinamika Manajemen Pendidikan (2017). 


\section{Pemberian Reward}

Reward adalah subtipe dari teori penguatan positif yang berasal dari behaviorisme. Untuk mendorong guru agar berkinerja baik, sangat penting untuk memberikan kompensasi kepada mereka. Istilah "reward" meliputi istilah "reward", "prize", "award", dan "award" ${ }^{19}$. Dalam konsep manajemen sekolah, reward merupakan salah satu teknik yang digunakan untuk memotivasi instruktur. digunakan untuk mengkorelasikan aktivitas dan tindakan guru dengan perasaan puas dan gembira, sehingga memotivasi guru untuk konsisten berkinerja baik.Selain insentif, penghargaan dimaksudkan untuk meningkatkan keterlibatan guru dalam tugas mengajar, dengan tujuan meningkatkan prestasi mereka ${ }^{20}$. Reward dapat diukur dalam aplikasinya menggunakan dimensi dan indikator berikut.

Tabel 2. Dimensi dan Indikator Reward

\begin{tabular}{ll}
\hline \multicolumn{1}{c}{ Dimensi } & \multicolumn{1}{c}{ Indikator } \\
\hline Penghargaan Ekstrinsik (Irham Fahmi, 2016) & Penghargaan finansial berupa Gaji \\
\hline & Penghargaan finansial berupa Tunjangan \\
\hline & Penghargaan finansial berupa Bonus \\
\hline & Penghargaan non finansial berupa Penghargaan Interpersonal \\
\hline Penghargaan Intrinsik (Irham Fahmi, 2016) & Penghargaan non finansial berupa Promosi \\
\hline & Penyelesaian (Completion) \\
\hline & Pencapaian (Achievement) \\
\hline & Otonomi \\
\hline
\end{tabular}

\section{Motivasi Guru}

Motivasi dapat didefinisikan sebagai dorongan internal yang mendorong seseorang untuk bergerak atau melakukan suatu kegiatan atau perilaku untuk mencapai tujuan yang telah ditetapkan. Seseorang yang bekerja membutuhkan motivasi yang disebut dengan motivasi kerja. Motivasi kerja yang tinggi dapat memotivasi seseorang untuk lebih aktif dan teliti dalam bekerja ${ }^{21}$. Motivasi kerja guru adalah keadaan pikiran di mana guru memiliki keinginan atau kebutuhan untuk mencapai tujuan tertentu melalui pelaksanaan suatu tugas. Motivasi guru dapat membangkitkan energi untuk bekerja atau akan mengarahkan tindakan saat bekerja, dan akan mengajarkan seorang guru bahwa

19 Agung Rahmanto, "PENINGKATAN KEDISIPLINAN GURU MELALUI PEMBERIAN REWARD DI SD MUHAMMADIYAH SAPEN YOGYAKARTA,” Tajdidukasi: Jurnal Penelitian dan Kajian Pendidikan Islam (2019).

${ }^{20}$ Rapi Monoarfa, "Penerapan Reward and Punishment Dalam Upaya Peningkatan Disiplin Kehadiran Mengajar Guru Di SDN 03 Duhiadaa," Aksara: Jurnal Ilmu Pendidikan Nonformal (2020).

21 Titin Eka Ardiana, "PENGARUH MOTIVASI KERJA GURU TERHADAP KINERJA GURU AKUNTANSI SMK DI KOTA MADIUN," JURNAL AKUNTANSI DAN PAJAK (2017). 
ada tujuan yang relevan baik dengan tujuan organisasi maupun pribadi ${ }^{22}$. Motivasi kerja guru berfungsi sebagai pedoman atau motivator dalam diri guru dalam rangka mencapai suatu tujuan atau cita-cita. Motivasi dapat berasal dari dalam diri manusia sebagai akibat dari kebutuhan yang dirasakan. Keinginan inilah yang memotivasi seseorang untuk melakukan tindakan menuju suatu tujuan. Tabel berikut merangkum aspek dan indikator motivasi guru sebagaimana diuraikan oleh ${ }^{23}$.

Tabel 3. Dimensi dan Indikator Motivasi Guru

\begin{tabular}{ll}
\hline \multicolumn{1}{c}{ Dimensi } & \multicolumn{1}{c}{ Indikator } \\
\hline Motivasi Internal & Tanggung jawab guru dalam melaksanakan tugas \\
\cline { 2 - 2 } & Melaksanakan tugas dengan target yang jelas \\
\cline { 2 - 2 } & Memiliki tujuan yang jelas dan menantang \\
\cline { 2 - 2 } & Ada umpan balik atas hasil pekerjaannya \\
\cline { 2 - 2 } & Memiliki perasaan senang dalam bekerja \\
\cline { 2 - 2 } & Selalu berusaha untuk mengungguli orang lain \\
\cline { 2 - 2 } Motivasi Eksternal & Diutamakan prestasi dari apa yang dikerjakan \\
\cline { 2 - 2 } & Selalu berusaha untuk memenuhi kebutuhan hidup dan kebutuhan kerjanya \\
\cline { 2 - 2 } & Senang memperoleh pujian dari apa yang dikerjakan \\
\cline { 2 - 2 } & Bekerja dengan harapan ingin memperoleh insentif \\
\hline
\end{tabular}

\section{Desain Penelitian}

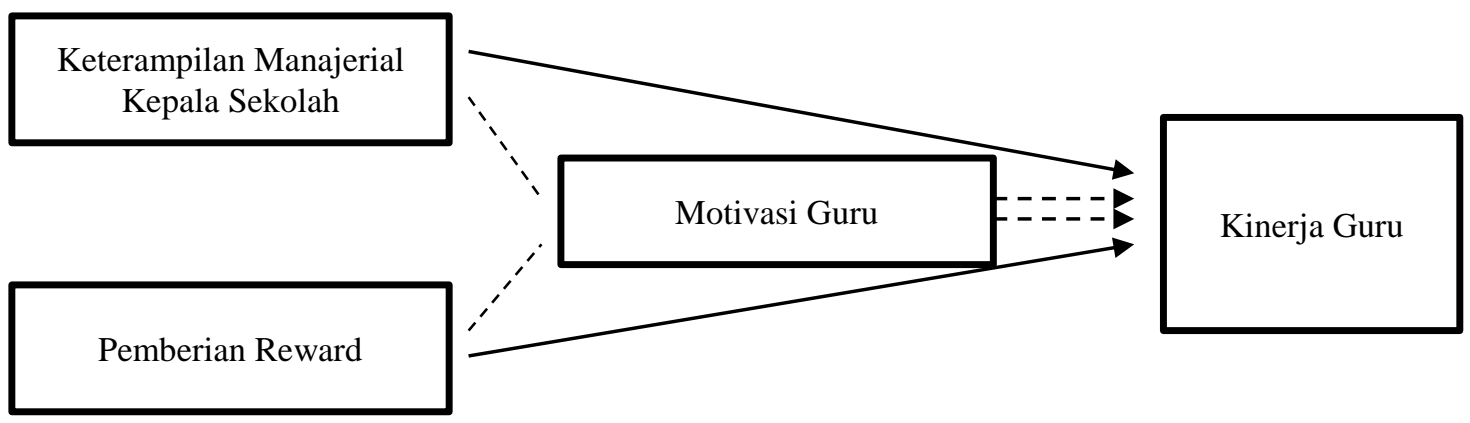

${ }^{22}$ Didi Pianda, Kinerja Guru: Kompetensi Guru, Motivasi Kerja Dan Kepemimpinan Kepala Sekolah, CV Jejak, 2018.

${ }^{23}$ B. Hamzah Uno, Theory of Motivation and Its Measurement Analysis in the Field of Education (Teori Motivasi Dan Pengukurannya Analisis Di Bidang Pendidikan), Bumi Aksara, 2010. 
Gambar 2. Rancangan Penelitian

Hipotesis:

H1 : Keterampilan Manajerial berpengaruh terhadap Kinerja Guru

H2 : Keterampilan Manajerial berpengaruh terhadap Motivasi Guru

H3 : Pemberian Reward berpengaruh terhadap Kinerja Guru

H4 : Pemberian Reward berpengaruh terhadap Motivasi Guru

H5 : Motivasi Guru berpengaruh terhadap Kinerja Guru

H6 : Keterampilan Manajerial berpengaruh terhadap Kinerja Guru melalui Motivasi Guru

H7 : Pemberian Reward berpengaruh terhadap Kinerja Guru melalui Motivasi Guru

\section{METODE PENELITIAN}

Penelitian ini menggunakan metode kuantitatif. Penelitian ini relevan karena bertujuan untuk menemukan hubungan sebab akibat antar variable yang diteliti ${ }^{24}$ Tujuan penelitian ini adalah untuk mengetahui motivasi guru sebagai variable perantara (intervensi), variable bebas yaitu kemampuan manajerial kepala sekolah serta pemberian reward dan kinerja guru sebagai variable terikat $^{25}$. Populasi dalam penelitian ini adalah guru SMP Negeri Lowokwaru sebanyak 100 orang. Metode pengambilan sampel yang digunakan dalam penelitian ini adalah total sampling. Karena jumlah sampel dalam penelitian ini adalah 100 maka seluruh anggota populasi dijadikan sampel penelitian. Metode pengumpulan data yang digunakan dalam penelitian ini menggunakan kuesioner tertutup. Survei ini menunjukkan bahwa pengumpulan data memiliki empat pilihan jawaban: satu jawaban sangat sering (SS), dua jawaban baik (S), tiga pertanyaan jarang (J), dan total empat jawaban (TP). Data survei dianalisis dengan metode analisis jalur menggunakan program SmartPLS.

${ }^{24}$ Sugiyono, Metode Penelitian Pendidikan Pendekatan Kuantitatif, Kualitatif, Dan R\&D (Bandung: Alfabeta, 2015).

Eva Puspita Vani and Ahmad Rizki Sridadi, "PENGARUH DISIPLIN TERHADAP KINERJA GURU SMPN DI KECAMATAN X DENGAN MOTIVASI SEBAGAI VARIABEL INTERVENING," JURNAL EKBIS (2020). 


\section{HASIL PENELITIAN}

\section{Outer Model}

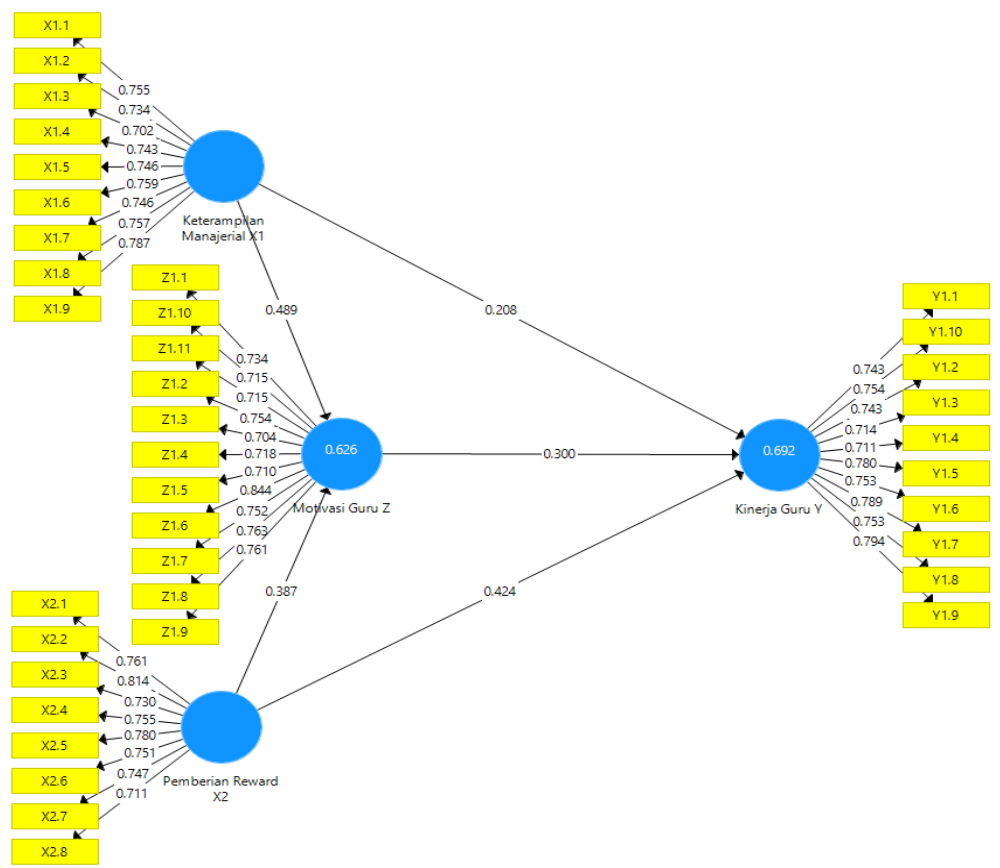

Gambar 2. Outer Model 
Tabel 4. Outer Model

\begin{tabular}{|c|c|c|c|c|}
\hline & $\begin{array}{c}\text { Keterampilan } \\
\text { Manajerial } \\
\text { X1 } \\
\end{array}$ & $\begin{array}{c}\text { Kinerja Guru } \\
\mathbf{Y}\end{array}$ & $\begin{array}{c}\text { Motivasi Guru } \\
\text { Z }\end{array}$ & $\begin{array}{c}\text { Pemberian } \\
\text { Reward } \\
\text { X2 }\end{array}$ \\
\hline $\mathrm{X} 1.1$ & 0.755 & & & \\
\hline $\mathrm{X} 1.2$ & 0.734 & & & \\
\hline $\mathrm{X} 1.3$ & 0.702 & & & \\
\hline X1.4 & 0.743 & & & \\
\hline X1.5 & 0.746 & & & \\
\hline $\mathrm{X} 1.6$ & 0.759 & & & \\
\hline $\mathrm{X} 1.7$ & 0.746 & & & \\
\hline $\mathrm{X} 1.8$ & 0.757 & & & \\
\hline X1.9 & 0.787 & & & \\
\hline $\mathrm{X} 2.1$ & & & & 0.761 \\
\hline $\mathrm{X} 2.2$ & & & & 0.814 \\
\hline $\mathrm{X} 2.3$ & & & & 0.730 \\
\hline$X 2.4$ & & & & 0.755 \\
\hline$X 2.5$ & & & & 0.780 \\
\hline $\mathrm{X} 2.6$ & & & & 0.751 \\
\hline $\mathrm{X} 2.7$ & & & & 0.747 \\
\hline$X 2.8$ & & & & 0.711 \\
\hline Y1.1 & & 0.743 & & \\
\hline Y1.2 & & 0.743 & & \\
\hline Y1.3 & & 0.714 & & \\
\hline Y1.4 & & 0.711 & & \\
\hline Y1.5 & & 0.780 & & \\
\hline Y1.6 & & 0.753 & & \\
\hline Y1.7 & & 0.789 & & \\
\hline Y1.8 & & 0.753 & & \\
\hline Y1.9 & & 0.794 & & \\
\hline Y1.10 & & 0.754 & & \\
\hline $\mathrm{Z1.1}$ & & & 0.734 & \\
\hline $\mathrm{Z1.2}$ & & & 0.754 & \\
\hline $\mathrm{Z1.3}$ & & & 0.704 & \\
\hline Z1.4 & & & 0.718 & \\
\hline Z1.5 & & & 0.710 & \\
\hline Z1.6 & & & 0.844 & \\
\hline $\mathrm{Z1.7}$ & & & 0.752 & \\
\hline $\mathrm{Z1.8}$ & & & 0.763 & \\
\hline $\mathrm{Z1.9}$ & & & 0.761 & \\
\hline $\mathrm{Z1.10}$ & & & 0.715 & \\
\hline Z1.11 & & & 0.715 & \\
\hline
\end{tabular}

Tabel tersebut menunjukkan apakah nilai beban eksternal keterampilan manajemen, gaji, kinerja guru, motivasi guru dan indikator lainnya telah mencapai minimum, karena nilai koefisien bebannya lebih besar dari 0,6. Hal ini menunjukkan bahwa semua flag dalam pengujian ini valid. 


\section{Construct Reliability and Validity}

Tabel 5. Construct Reliability and Validity

\begin{tabular}{lllll}
\hline & $\begin{array}{l}\text { Cronbach's } \\
\text { Alpha }\end{array}$ & rho_A & $\begin{array}{l}\text { Composite } \\
\text { Reliability }\end{array}$ & $\begin{array}{l}\text { Average Variance } \\
\text { Extracted (AVE) }\end{array}$ \\
\hline Keterampilan Manajerial X1 & 0.902 & 0.903 & 0.920 & 0.560 \\
\hline Kinerja Guru Y & 0.915 & 0.916 & 0.929 & 0.568 \\
\hline Motivasi Guru Z & 0.919 & 0.921 & 0.931 & 0.553 \\
\hline Pemberian Reward X2 & 0.893 & 0.897 & 0.915 & 0.573
\end{tabular}

Selain menggunakan nilai crossload, Anda dapat memeriksa uji validitas diskriminan dari mean of variance (AVE) ekstrak. Pada tabel tersebut dapat dilihat bahwa semua indikator yang digunakan untuk kemampuan manajemen, reward, kinerja guru, dan motivasi guru dinyatakan valid karena nilai AVE lebih besar dari 0,5 .

Skor keterampilan manajemen penghargaan pada Tabel 5 menunjukkan bahwa skor kepercayaan komprehensif untuk semua variable yang digunakan dalam penelitian ini (seperti kinerja guru, motivasi guru, dll.) melebihi 0,7. Reliabilitas komprehensif keterampilan manajemen 0,920, gain 0,915, motivasi guru 0,931, dan kinerja guru 0,929. Dalam pernyataan ini, kita dapat mengatakan bahwa setiap indikator dari setiap variable dinyatakan stabil, akurat dan konsisten untuk mengukur variable.

\section{R Square}

Tabel 6. R Square

\begin{tabular}{lll}
\hline & R Square & R Square Adjusted \\
\hline Kinerja Guru Y & 0.692 & 0.682 \\
\hline Motivasi Guru Z & 0.626 & 0.619 \\
\hline
\end{tabular}

Dari data diatas didapatkan nilai R-square bahwa variable kinerja guru dipengaruhi keterampilan manajerial kepala sekolah dan pemberian reward sebesar $69,2 \%$ sementara $30,8 \%$ yang mempengaruhi variable lain diluar variable yang diteliti. Pada variable motivasi guru dipengaruhi oleh keterampilan manajerial kepala sekolah dan pemberian reward 62,6\% sementara $37,4 \%$ dipengaruhi oleh variable lain diluar variable yang diteliti. 


\section{Inner Model}

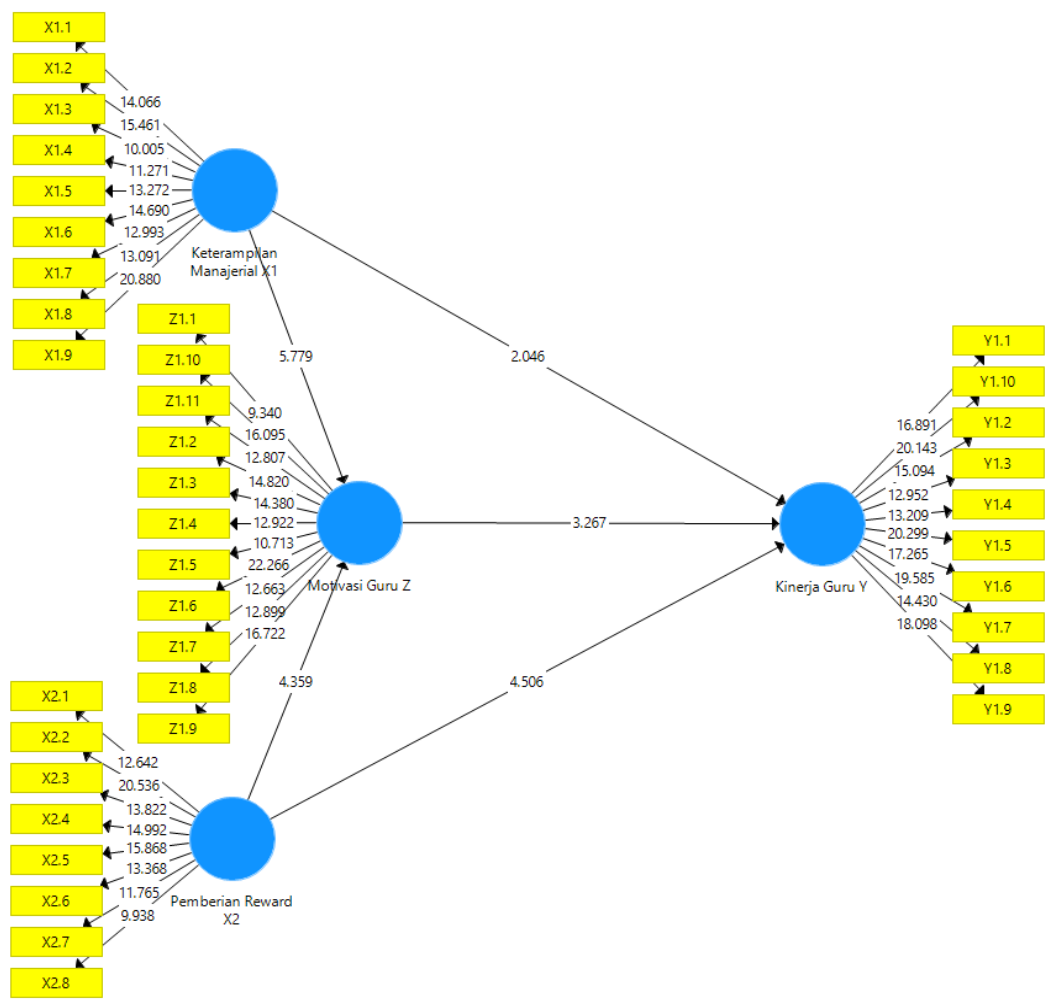

Gambar 3. Inner Model

\section{Path Coeficient}

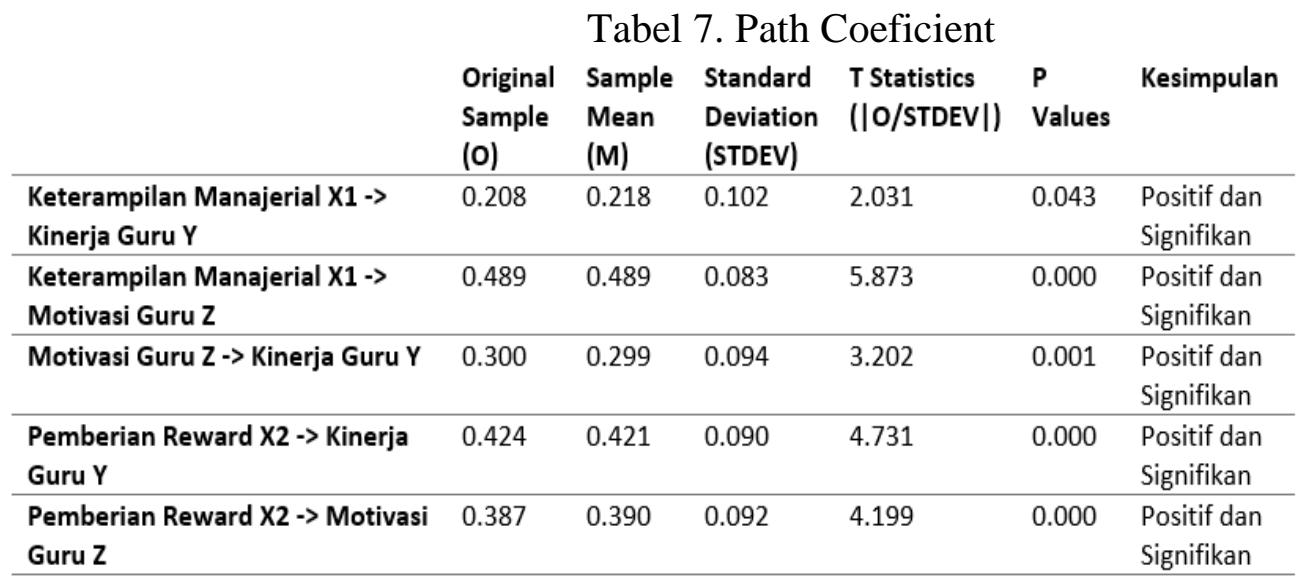




\section{Specific Indirect Effects}

Tabel 8. Specific Indirect Effects

\begin{tabular}{lllllll}
\hline & $\begin{array}{l}\text { Original } \\
\text { Sample } \\
(\mathbf{O})\end{array}$ & $\begin{array}{l}\text { Sample } \\
\text { Mean } \\
\text { (M) }\end{array}$ & $\begin{array}{l}\text { Standard } \\
\text { Deviation } \\
\text { (STDEV) }\end{array}$ & $\begin{array}{l}\text { T Statistics } \\
\text { (|O/STDEV|) }\end{array}$ & $\begin{array}{l}\text { P } \\
\text { Values }\end{array}$ & Kesimpulan \\
\hline $\begin{array}{l}\text { Keterampilan Manajerial X1 }>> \\
\text { Motivasi Guru Z }->\text { Kinerja Guru Y }\end{array}$ & 0.147 & 0.146 & 0.054 & 2.740 & 0.006 & $\begin{array}{l}\text { Positif dan } \\
\text { Signifikan }\end{array}$ \\
\hline $\begin{array}{l}\text { Pemberian Reward X2 }>\text { Motivasi } \\
\text { Guru Z -> Kinerja Guru Y }\end{array}$ & 0.116 & 0.117 & 0.049 & 2.359 & 0.019 & $\begin{array}{l}\text { Positif dan } \\
\text { Signifikan }\end{array}$ \\
\hline
\end{tabular}

Tabel 9. Hasil Kesimpulan Hipotesis

\begin{tabular}{llc}
\hline & \multicolumn{1}{c}{ Hipotesis } & Hasil \\
\hline H1 & Keterampilan Manajerial berpengaruh terhadap Kinerja Guru & Diterima \\
\hline H2 & Keterampilan Manajerial berpengaruh terhadap Motivasi Guru & Diterima \\
\hline H3 & Pemberian Reward berpengaruh terhadap Kinerja Guru & Diterima \\
\hline H4 & Pemberian Reward berpengaruh terhadap Motivasi Guru & Diterima \\
\hline H5 & Motivasi Guru berpengaruh terhadap Kinerja Guru & Diterima \\
\hline H6 & Keterampilan Manajerial berpengaruh terhadap Kinerja Guru melalui Motivasi Guru & Diterima \\
\hline H7 & Pemberian Reward berpengaruh terhadap Kinerja Guru melalui Motivasi Guru & Diterima \\
\hline
\end{tabular}

\section{PEMBAHASAN}

\section{Pengaruh Keterampilan Manajerial Kepala Sekolah terhadap Kinerja} Guru

Berdasarkan hasil perhitungan statistik pengaruh keterampilan manajerial kepala sekolah terhadap kinerja guru menunjukkan p-value $(0,043 \leq$ 0,05). Hal ini menunjukkan bahwa terdapat hubungan yang signifikan antara variable keterampilan manajerial kepala sekolah terhadap kinerja guru. Hasil penelitian ini juga mendukung penelitian yang dilakukan oleh ${ }^{26}$ Keterampilan manajemen madrasah berdampak positif terhadap kinerja guru. Prestasi guru dapat dipahami dengan kemampuan guru dalam menyelesaikan tugas-tugas guna mencapai hasil yang terlihat atau terlihat. Kemampuan kepala sekolah dalam memimpin dan memotivasi guru memiliki pengaruh yang signifikan terhadap kinerja bisnis.

\section{Pengaruh Keterampilan Manajerial Kepala Sekolah terhadap Motivasi Guru}

Berdasarkan hasil perhitungan statistik pengaruh keterampilan manajerial kepala sekolah terhadap motivasi guru menunjukkan $p$-value $(0,000$ $\leq 0,05$ ). Hal ini menunjukkan bahwa terdapat hubungan yang signifikan antara variable keterampilan manajerial kepala sekolah terhadap motivasi guru. Hasil

26 Irwandi Mamonto, Rivai Bolotio, and Ardianto Ardianto, "Pengaruh Perilaku Kepemimpinan Dan Keterampilan Manajerial Kepala Madrasah Terhadap Kinerja Guru Di Man 1 Kotamobagu," Journal of Islamic Education Policy (2020). 
penelitian ini juga mendukung penelitian yang dilakukan oleh ${ }^{27}$ Kemampuan manajemen direktur Madrasah sangat berpengaruh terhadap jadwal kerja guru. Keterampilan manajemen adalah salah satu keterampilan yang harus dimiliki manajer ketika mempertimbangkan pentingnya teknologi ini. Para pengurus madrasah harus mampu secara terus menerus meningkatkan keterampilannya dalam menjalankan tugas, peran dan fungsinya, serta bekerja sama untuk mencapai tujuan khususnya semua bidang pendidikan. Tujuan sistem. Kepala sekolah harus mendorong pendidik untuk melakukan tugas dan fungsi penting untuk mencapai tujuan visi dan misi mereka, dan memotivasi mereka untuk melakukan pekerjaan mereka.

\section{Pengaruh Pemberian Reward berpengaruh terhadap Kinerja Guru}

Berdasarkan hasil perhitungan statistik pengaruh pemberian reward terhadap kinerja guru menunjukkan p-value $(0,000 \leq 0,05)$. Hal ini menunjukkan bahwa terdapat hubungan yang signifikan antara variable pemberian reward terhadap kinerja guru. Hasil penelitian ini juga mendukung penelitian yang dilakukan oleh ${ }^{28}$ Penghargaan Profesor Emeritus Ini memiliki pengaruh besar pada kinerja tugas. Pembekalan guru honorer (1) meningkatkan rasa tanggung jawab guru terhadap tugasnya, (2) bersedia bekerja di luar standar kerja yang ditetapkan, (3) aktif melaksanakan tugasnya, dan (4) positif. efek. Kesediaan untuk bekerja. Pekerjaan rumah, administrasi dan keterampilan pendidikan. Pengaruh Perdana Menteri terhadap prestasi guru honorer diawali dengan penghargaan, harga diri atas prestasi, prestasi, dan loyalitas terhadap lembaga dan lembaga pendidikan.

\section{Pengaruh Pemberian Reward berpengaruh terhadap Motivasi Guru}

Berdasarkan hasil perhitungan statistik pengaruh pemberian reward terhadap motivasi guru menunjukkan p-value $(0,000 \leq 0,05)$. Hal ini menunjukkan bahwa terdapat hubungan yang signifikan antara variable pemberian reward terhadap motivasi guru. Hasil penelitian ini juga mendukung penelitian yang dilakukan oleh ${ }^{29}$ meskipun memiliki subjek penelitian yang berbeda namun hasil yang didapatkan sama yakni XIPS MA Mathlaul Anwar Pontianak Kelas Ekonomi sangat membantu untuk merangsang belajar. Efek ini

${ }^{27}$ Moh Ali Akbar, "Pengaruh Kemampuan Manajerial Kepala Madrasah Dan Iklim Psikologis Terhadap Kinerja Guru Madrasah Tsanawiyah Negeri Lahat," Studia Manageria (2019).

${ }^{28}$ R Kurniawan, I., Harapan, E., \& Rohana, "Pengaruh Pemberian Penghargaan Terhadap Kinerja Guru Honorer Sekolah Menengah Atas Di Kota Sekayu, Musi Banyuasin, Sumatera Selatan," Jurnal Manajemen Pendidikan: Jurnal Ilmiah Administrasi, Manajemen dan Kepemimpinan Pendidikan 3, no. 1 (2021): 1-18.

29 N. Tafsil, M., Matsum, J. H., \& Asriati, "PENGARUH REWARD DAN PUNISHMENT TERHADAP MOTIVASI BELAJAR PADA MATA PELAJARAN EKONOMI MA MATHLAUL ANWAR," Jurnal Pendidikan Dan Pembelajaran Khatulistiwa 8, no. 9 (2019). 
mungkin disebabkan oleh bentuk penghargaan, bagaimana guru memberi penghargaan kepada siswa, dan bagaimana siswa mengevaluasi penghargaan guru. Oleh karena itu, reward dapat dijadikan sebagai motivasi untuk meningkatkan motivasi belajar siswa. Teori bahwa reward dapat meningkatkan motivasi belajar siswa adalah benar.

\section{Pengaruh Motivasi Guru berpengaruh terhadap Kinerja Guru}

Berdasarkan hasil perhitungan statistik pengaruh motivasi guru terhadap kinerja guru menunjukkan p-value $(0,001 \leq 0,05)$. Hal ini menunjukkan bahwa terdapat hubungan yang signifikan antara variable motivasi guru terhadap kinerja guru. Hasil penelitian ini juga mendukung penelitian yang dilakukan oleh ${ }^{30}$ Hipotesis tidak diterima dan menyatakan bahwa motivasi kerja guru berpengaruh signifikan terhadap kinerja guru. Kinerja seorang guru dapat dilihat atau diukur terhadap standar yang seharusnya dimiliki seorang guru. Pencapaian guru dalam konteks ini mengacu pada kemampuan dan keberhasilan guru dalam melaksanakan tugas-tugas pembelajaran seperti (1) kemampuan menulis rencana pendidikan, (2) kemampuan mencapai hasil belajar, dan (3) kemampuan membangun hubungan interpersonal. serta (4) kemampuan mengevaluasi hasil belajar. (5) Kemampuan melakukan pengayaan. (6) Kemampuan untuk melakukan operasi pemulihan. Oleh karena itu, guru harus termotivasi untuk bekerja untuk memastikan kinerjanya memenuhi harapan. Motivasi adalah faktor pendorong yang memungkinkan orang untuk menjalankan fungsinya.

\section{Pengaruh Keterampilan Manajerial Kepala Sekolah terhadap Kinerja Guru Melalui Motivasi Guru}

Berdasarkan hasil perhitungan statistik pengaruh keterampilan manajerial kepala sekolah terhadap kinerja guru melalui Motivasi Guru menunjukkan p-value $(0,006 \leq 0,05)$. Hal ini menunjukkan bahwa terdapat hubungan yang signifikan antara variable motivasi guru terhadap kinerja guru. Hasil penelitian ini juga mendukung penelitian yang dilakukan oleh ${ }^{31}$ Peran penting adalah untuk sebagian mengganggu pengaruh kepemimpinan kepala sekolah terhadap motivasi guru profesional sekolah. Temuan ini juga sesuai dengan teori Robert House tentang leadership on the road yang menyatakan bahwa kepemimpinan yang efektif berdampak positif terhadap motivasi dan

${ }^{30}$ S. Jumika, M. J. M., Suarman, S., \& Sumarno, "Pengaruh Motivasi Kerja Guru Terhadap Kinerja Guru SMP Negeri 6 Pekanbaru," Jurnal Online Mahasiswa Fakultas Ekonomi Universitas Riau (2015).

31 W. Agung, "PENGARUH KEPEMIMPINAN KEPALA SEKOLAH TERHADAP KINERJA GURU PROGRAM BISNIS DAN MANAJEMEN DI SMK NEGERI SE-KOTA SEMARANG DENGAN MOTIVASI KERJA SEBAGAI VARIABEL INTERVENING" (Universitas Negeri Semarang, 2015). 
kinerja guru. ${ }^{32}$ percaya bahwa kepemimpinan manajerial merupakan stimulus terhadap persepsi, emosi dan perilaku yang menentukan sikap bawahan. Seorang kepala sekolah dengan kepemimpinan yang efektif akan mengembangkan tingkat kepatuhan, loyalitas, kepercayaan diri, dan semangat yang tinggi, memungkinkan guru bekerja sama untuk mencapai tujuan sekolah dan mengembangkan pengetahuan guru yang baik.

\section{Pengaruh Pemberian Reward terhadap Kinerja Guru Melalui Motivasi Guru}

Berdasarkan hasil perhitungan statistik, pengaruh reward prestasi kerja guru melalui motivasi guru ditunjukkan dengan p-value $(0,0190,05)$. Hal ini menunjukkan bahwa terdapat hubungan yang signifikan antara variable motivasi guru dengan kinerja guru. Hasil dari penelitian ini adalah ${ }^{33}$ Insentif materi tidak secara langsung mempengaruhi kinerja guru, tetapi melalui insentif secara tidak langsung mempengaruhi kinerja guru. Insentif materi berpengaruh positif signifikan terhadap rangsangan, dan rangsangan berpengaruh positif signifikan terhadap kinerja guru. Insentif material merupakan salah satu faktor yang memotivasi orang untuk meningkatkan prestasi kerjanya. Memberikan insentif untuk zat yang memenuhi kebutuhan dan kebutuhan orang memotivasi orang untuk mengoptimalkan keterampilan mereka demi kinerja organisasi yang efisien dan lebih baik..

\section{KESIMPULAN}

Sesuai dengan hasil penganalisisan data serta pembahaszan yang dilakukan maka memperoleh beberapa kesimpulan bahwa:

1. Kinerja manajerial kepala sekolah memiliki pengaruh yang signifikan terhadap kinerja guru. Kemampuan memimpin yang dimiliki kepala sekolah bisa menjadikan guru dan staf merasa diayomi dengan baik sehingga hal ini bisa meningkatkan kinerja.

2. Kinerja manajerial kepala sekolah mempunyai pengaruh yang signfikan kepada motivasi guru. Pada penerapan sistem manajerial yang bijak dan dorongan positif yang diberikan kepada guru maka bisa mempengaruhi motivasi yang dimiliki guru.

3. Pemberian reward mempunyai pengaruh yang signiflkan terhadap kekinerja guru. Pemberian apresiasi berupa reward bisa mendorong

${ }^{32}$ Jeffrey A Matteson and Justin A Irving, "Servant versus Self-Sacrificial Leadership: A Behavioral Comparison of Two Follow-Oriented Leadership Theories," International Journal of Leadership Studies (2006).

${ }^{33}$ Cornelius Pasaribu and Irsutami, "Pengaruh Insentif Terhadap Kinerja Guru Pada Sekolah Menengah Atas Negeri (SMAN) Dengan Motivasi Sebagai Variabel Intervening," Jurnal Akuntansi, Ekonomi dan Manajemen Bisnis Politeknik Negeri Batam (2015). 
perilaku guru diperuntukan terus menambah kinerjanya.

4. Pemberian reward mempunyai pengaruh yang signlfikan terhadap motivasi untuk guru. Pemberian insentif dapat mengasih pendorongan semangat serta menjadi motivasi untuk guru.

5. Motivasi guru yang mempunyai pengaruh signiflkan terhadap kekinerjanya. Hall ini dikarenakan melalui dorongan dalam diri guru bisa menjadikannya total dalam melaksanakan pekerjaan yang mempengaruhi kinerjanya.

6. Kinerja manajerial untuk kepala sekolah mempunyai pengaruh signifikan kepada kekinerjaan guru bersamaan motivasi sebagai variable mediasi. Kinerja manajerial yang didorong oleh motivasi yang berada kedalam diri guru bisa melahirkan kinerja yang baik.

7. Pemberian reward memiliki pengaruh yang signlfikan kepada kinerja guru bersama motivasi menjadi variable mediasi. Pemberian reward bisa memantik motivasi serta hal berikut dapat berdampak pada kinerja yang dilakukan oleh guru.

\section{DAFTAR PUSTAKA}

Agung, W. "PENGARUH KEPEMIMPINAN KEPALA SEKOLAH TERHADAP KINERJA GURU PROGRAM BISNIS DAN MANAJEMEN DI SMK NEGERI SE-KOTA SEMARANG DENGAN MOTIVASI KERJA SEBAGAI VARIABEL INTERVENING." Universitas Negeri Semarang, 2015.

Akbar, Moh Ali. "Pengaruh Kemampuan Manajerial Kepala Madrasah Dan Iklim Psikologis Terhadap Kinerja Guru Madrasah Tsanawiyah Negeri Lahat.” Studia Manageria (2019).

Andriani, Septi, Nila Kesumawati, and Muhammad Kristiawan. "The Influence of the Transformational Leadership and Work Motivation on Teachers Performance." International Journal of Scientific and Technology Research (2018).

Ardiana, Titin Eka. "PENGARUH MOTIVASI KERJA GURU TERHADAP KINERJA GURU AKUNTANSI SMK DI KOTA MADIUN." JURNAL AKUNTANSI DAN PAJAK (2017).

Ariyanti, Yulekhah. "Keterampilan Manajerial Kepala Sekolah Dalam Meningkatkan Kinerja Guru.” AKSES: Jurnal Ekonomi dan Bisnis (2020).

Azis, Aissah Qomaria, and Suwatno Suwatno. "Pengaruh Gaya Kepemimpinan Kepala Sekolah Terhadap Kinerja Guru Di SMK Negeri 11 Bandung." Jurnal Pendidikan Manajemen Perkantoran (2019).

Ekosiswoyo, Rasdi. "Kepemimpinan Kepala Sekolah Yang Efektif Kunci Pencapaian Kualitas Pendidikan.” Jurnal Ilmu Pendidikan (2016).

Elliott, Kerry. "Teacher Performance Appraisal: More about Performance or Development?” Australian Journal of Teacher Education (2015). 
Irawan, Yudie, Nanik Susanti, and Wiwit Agus Triyanto. "ANALISA DAN PERANCANGAN SISTEM PEMBELAJARAN ONLINE (E-LEARNING) PADA SMK MAMBAUL FALAH KUDUS." Simetris: Jurnal Teknik Mesin, Elektro dan Ilmu Komputer (2015).

Jumika, M. J. M., Suarman, S., \& Sumarno, S. "Pengaruh Motivasi Kerja Guru Terhadap Kinerja Guru SMP Negeri 6 Pekanbaru." Jurnal Online Mahasiswa Fakultas Ekonomi Universitas Riau (2015).

Kartomo, Andhika Imam, and Slameto Slameto. "EVALUASI KINERJA GURU BERSERTIFIKASI.” Kelola: Jurnal Manajemen Pendidikan (2016).

Kurniawan, I., Harapan, E., \& Rohana, R. "Pengaruh Pemberian Penghargaan Terhadap Kinerja Guru Honorer Sekolah Menengah Atas Di Kota Sekayu, Musi Banyuasin, Sumatera Selatan.” Jurnal Manajemen Pendidikan: Jurnal Ilmiah Administrasi, Manajemen dan Kepemimpinan Pendidikan 3, no. 1 (2021): 1-18.

Laschinger, Heather K.Spence, Joan E. Finegan, Judith Shamian, and Piotr Wilk. "A Longitudinal Analysis of the Impact of Workplace Empowerment on Work Satisfaction.” Journal of Organizational Behavior (2004).

Li, Yuan, Yongbin Zhao, and Yi Liu. "The Relationship between HRM, Technology Innovation and Performance in China." International Journal of Manpower (2006).

Makhmudah, Siti. “Upaya Memperbaiki Kualitas Guru Dengan Memaksimalkan Terpenuhinya Kompetensi Kepribadian Dan Profesionalisme Guru." Jurnal Studi Islam (2016).

Mamonto, Irwandi, Rivai Bolotio, and Ardianto Ardianto. "Pengaruh Perilaku Kepemimpinan Dan Keterampilan Manajerial Kepala Madrasah Terhadap Kinerja Guru Di Man 1 Kotamobagu." Journal of Islamic Education Policy (2020).

Matteson, Jeffrey A, and Justin A Irving. "Servant versus Self-Sacrificial Leadership: A Behavioral Comparison of Two Follow-Oriented Leadership Theories." International Journal of Leadership Studies (2006).

Monoarfa, Rapi. "Penerapan Reward and Punishment Dalam Upaya Peningkatan Disiplin Kehadiran Mengajar Guru Di SDN 03 Duhiadaa.” Aksara: Jurnal Ilmu Pendidikan Nonformal (2020).

Özyurt, Özcan, Hacer Özyurt, Adnan Baki, Bülent Güven, and Hasan Karal. "Evaluation of an Adaptive and Intelligent Educational Hypermedia for Enhanced Individual Learning of Mathematics: A Qualitative Study." Expert Systems with Applications (2012).

Pasaribu, Cornelius, and Irsutami. "Pengaruh Insentif Terhadap Kinerja Guru Pada Sekolah Menengah Atas Negeri (SMAN) Dengan Motivasi Sebagai Variabel Intervening." Jurnal Akuntansi, Ekonomi dan Manajemen Bisnis Politeknik Negeri Batam (2015).

Pianda, Didi. Kinerja Guru: Kompetensi Guru, Motivasi Kerja Dan Kepemimpinan Kepala Sekolah. CV Jejak, 2018.

Putri, Dini Palupi. "Pendidikan Karakter Pada Anak Sekolah Dasar Di Era Digital." AR-RIAYAH : Jurnal Pendidikan Dasar (2018).

Rahmanto, Agung. "PENINGKATAN KEDISIPLINAN GURU MELALUI 
PEMBERIAN REWARD DI SD MUHAMMADIYAH SAPEN YOGYAKARTA." Tajdidukasi: Jurnal Penelitian dan Kajian Pendidikan Islam (2019).

Saputra, Bagus. "KETERAMPILAN MANAJERIAL KEPALA SEKOLAH PADA SEKOLAH UMUM BERCIRI KHAS ISLAM DI SEKOLAH DASAR ISLAM TERPADU (SDIT).” Jurnal Manajemen dan Supervisi Pendidikan (2018).

Sholeh, Muhamad. "Keefektifan Peran Kepala Sekolah Dalam Meningkatkan Kinerja Guru." Jurnal Dinamika Manajemen Pendidikan (2017).

Sugiyono. Metode Penelitian Pendidikan Pendekatan Kuantitatif, Kualitatif, Dan $R \& D$. Bandung: Alfabeta, 2015.

Suhartatik, Ani, and P.Julius F Nagel. "Pengaruh Faktor Motivasi Terhadap Kepuasan Kerja Dan Kinerja Pada Guru Sekolah Menegah Atas (SMA) Di Surabaya." Prosiding Seminar Nasional Multi Disiplin Ilmu \& Call For Pappers UNISBANK (SENDI_U) (2016).

Syukri. "Peranan Kepemimpinan Kepala Sekolah Dalam Meningkatkan Kinerja Guru Pada SMP Nurul Ihsan Kabupaten Tolitoli.” Tesis, 2012.

Tafsil, M., Matsum, J. H., \& Asriati, N. "PENGARUH REWARD DAN PUNISHMENT TERHADAP MOTIVASI BELAJAR PADA MATA PELAJARAN EKONOMI MA MATHLAUL ANWAR." Jurnal Pendidikan Dan Pembelajaran Khatulistiwa 8, no. 9 (2019).

Uno, B. Hamzah. Theory of Motivation and Its Measurement Analysis in the Field of Education (Teori Motivasi Dan Pengukurannya Analisis Di Bidang Pendidikan). Bumi Aksara, 2010.

Vani, Eva Puspita, and Ahmad Rizki Sridadi. "PENGARUH DISIPLIN TERHADAP KINERJA GURU SMPN DI KECAMATAN X DENGAN MOTIVASI SEBAGAI VARIABEL INTERVENING." JURNAL EKBIS (2020).

Wahab, Jamalullail Abdul, Ahmad Zamri Mansor, Muhammad Hussin, and Sharla Kumarasamy. "Headmasters' Instructional Leadership and Its Relationship with Teachers Performance." Universal Journal of Educational Research (2020).

Zuhdiah, Zuhdiah. "MENINGKATKAN MOTIVASI KERJA GURU MELALUI PEMBERIAN REWARD DAN PUNISHMENT.” Vidya Karya (2019). 